\title{
THE USAGE EFFECTIVITY OF PROJECT-BASED INTERACTIVE E-MODULE IN IMPROVING STUDENTS’ ACHIEVEMENT
}

\author{
Komang Redy Winatha ${ }^{1}$ and Myra Mentari Abubakar ${ }^{2}$ \\ ${ }^{1}$ STMIK STIKOM Indonesia, Bali, Indonesia \\ ${ }^{2}$ School of Culture, History \& Language, Australian National University, Australia \\ E-mail: redywin@stiki-indonesia.ac.id
}

\begin{abstract}
One of the changes done by the government in the field of education is changing Curriculum 2006 to be Curriculum 2013. This change impacts on the change of learning paradigm, which at the beginning it was teacher-centered learning changes to be students centered learning. Therefore, the learning strategy used by teachers should be addressed to facilitate competence achievement that in the end, it will improve students' achievement. This study was aimed to identify the effectivity of project-based interactive e-module media towards students' achievement in the subject of digital simulation. This study was categorized into preexperimental quantitative research with one group pretest-posttest design. The data analysis method used was a paired sample t-test. The results showed the significance value obtained was 0.000 which means higher than $\alpha$. This means that there is an average score difference of students' achievement between before and after using the project based interactive e-module. The post-test average score is 82.65 which is higher than the average pre-test score of 43.40 . It can be concluded that digital simulation learning by using the project based interactive emodule can improve the students' achievement.
\end{abstract}

Keywords: effectivity, interactive e-module, project-based learning, students' achievement

\section{INTRODUCTION}

Digital simulation is included in the group of productive subjects which is compulsory for all expertise programs at grade $\mathrm{X}$ of Vocational High School. This subject teaches how to utilize information, communication, and technology which is very necessary nowadays in the labor world. The skills meant here are such as digital information management through software of information processing (data processing, numbers, and presentation), and online network communication. Beside that, this subject aims to equip skills for the students to communicate their ideas or concepts they find by themselves or modify existed ideas or concepts through digital media.

The subject of digital simulation must be acquired by students maximally. However, much time allocation for learning is required thus it needs good time management for the students to acquire all basic competence contained in the syllabus. With time allocation which is only 3 hours per week, it is improbable for students to acquire all expected competence if only done at the school until students frequently experience obstacles and difficulties during the learning process. This condition becomes more severe because of the lack of media availability either in the form of printed media or electronic ones.

The material characteristics demand the existence of facilities that support the learning process and in accordance with the curriculum which emphasizes innovative learning. The implementation of learning can be supported with relevant learning facilities. One of the learning facilities that can be used is a teaching material in the form of modules.

Technology development that is getting faster propels the replacement of printed technology with computer technology in learning activities. Modules as one of the printed learning media, their presentation is transformed into electronic form until it creates the new term which is electronic modules or knows as e-modules. The usage of e-modules in 
the learning process will grow creativity, productive thinking habits, creating an active condition, effective, innovative, and fun [1].

Based on that foundation, the development and the application of e-module based learning for Vocational high School TI Bali Global Singaraja is very necessary. Beforehand, the researcher had developed a project based interactive module for the subject of digital simulation [2]. The developed interactive e-module development was limited at the development step only, and its effectivity in classroom learning was never be tested.

This e-module, developed based on a project-based learning model, presents project task as the main activity. The application of learning innovation in the form of giving project tasks as the materials will improve students' understanding towards expected competence. Choosing project-based learning model is based on some considerations such as, (a) Project-based learning is one of innovative learning model that involves students in problem-solving activity and give chance to work in team autonomously construct their own learning in accordance with the demands of Curriculum 2013; (b) It is very relevant to productive subject of Vocational High School that emphasizes on skills acquisition. The project-based learning approach gives alternative of an authentic learning environment in which it eases students to improve their skills in working and solving problem collaboratively; (c) Based on the research that had been conducted, project-based learning is proven effective in improving study motivation [3], improving the process, and achievement [4], improving the ability of solving problem in various situations [5], giving skills to students to learn independently [6], and improving achievement [7].

By using this project based interactive emodule, students are guided to learn to find their knowledge by following project-based learning steps thus the knowledge obtained is more meaningful and adhered to students. The combination of electronic teaching media in the form of e-module and project-based learning will be an excellent collaboration in learning product innovation. The implementation of project-based learning collaborated with Information, and Communication Technologies (ICT) can generate a positive learning environment where the students can actively participate in the process of knowledge and skills construction [8]. The higher learning advantage will be obtained if the instruction given is assisted with computer technology compared to traditional methods [9].

From various explanations, then the researcher is interested in using project-based interactive e-module as effective learning media to improve students' achievement in the subject of digital simulation at Vocational High school TI Bali Global Singaraja.

\section{METHOD}

This study is quantitative preexperimental research with one group pretestposttest design (before and after). The experiment was conducted on one group without a comparative group. In this design, at the beginning of the research activity, measurement towards the dependent variable that has been owned by the subject was conducted. After giving the treatment, measurement towards the dependent variable with the same measurement tool was conducted again. The subjects in this study consisted of 21 students of grade X Multimedia at Vocational High School TI Bali Global Singaraja.

This study analyzed two variables. They are the project based interactive e-module as the independent variable and the students' achievement as the dependent variable. The measurement tool used in this study was an achievement test to examine the students' achievement after following the learning process with the project based interactive emodule. There were two kinds of achievement test developed; they are an essay test and a performance test. The essay test required students to organize, formulate, and deliver 
their opinions. Performance assessment referred to students' performance in doing one working unit. This study prioritized the action implementation or students' performance. This assessment covered observation towards specific behavior that can be done or evaluation towards the product.

The study was started with the step of organizing the learning environment. The purpose was to ensure that the class and the facility needed had been provided before the experiment was conducted. This step was conducted to assist in achieving the message delivery (the learning process) effectively ran without any troubles. Then the researcher collected 21 subjects from grade X Multimedia students.

The pre-test score was obtained from the results of the achievement test given to all students during the process of collecting the samples. Afterward, a treatment in the form of project-based interactive e-module for three meetings was conducted. Next, an achievement test for the post-test was conducted after the treatment of the samples was done. During the study, an observation of the research subject was carried out. The data analysis method used was a paired sample t-test to compare the average scores of students' achievement before and after being treated with the project based interactive e-module.

\section{RESULTS AND DISCUSSION}

A pretest and a posttest were conducted to examine the difference between the average scores of the students' achievement before and after the use of the project based interactive emodule. The results of pretest and posttest scores are presented in Table 1. The mean scores differences in students' achievement before and after the treatment were further analyzed with paired sample t-test analysis. Table 2 summarizes the results of the paired sample t-test.
Table 1. The Result Scores of the Pretest and the Posttest

\begin{tabular}{ccc}
\hline Subject & Pretest & Posttest \\
\hline 1 & 46.97 & 75.57 \\
2 & 43.95 & 79.55 \\
3 & 53.37 & 83.72 \\
4 & 43.75 & 82.58 \\
5 & 42.62 & 84.17 \\
6 & 43.56 & 82.77 \\
7 & 41.67 & 87.13 \\
8 & 42.43 & 86.93 \\
9 & 73.68 & 93.56 \\
10 & 41.48 & 87.13 \\
11 & 31.82 & 80.31 \\
12 & 33.72 & 84.66 \\
13 & 47.54 & 80.50 \\
14 & 59.66 & 85.80 \\
15 & 64.97 & 82.39 \\
16 & 29.36 & 81.63 \\
17 & 40.34 & 79.55 \\
18 & 33.72 & 80.50 \\
19 & 37.88 & 81.45 \\
20 & 27.28 & 77.28 \\
21 & 31.63 & 78.41 \\
\hline
\end{tabular}

Table 2. The Results of the Paired Sample T-Test

\begin{tabular}{|c|c|c|c|c|c|}
\hline \multirow{2}{*}{ Group } & \multirow{2}{*}{$\mathrm{n}$} & \multicolumn{2}{|c|}{ Average Score } & \multirow{2}{*}{$\mathrm{t}$} & \multirow{2}{*}{ Sig } \\
\hline & & Pretest & Posttest & & \\
\hline $\begin{array}{l}\text { pretest- } \\
\text { posttest }\end{array}$ & 21 & 43.40 & 82.65 & $\begin{array}{c}- \\
17.8\end{array}$ & .000 \\
\hline
\end{tabular}

Based on the analysis of the paired sample t-test, the significance value was 000 with a significance level of $5 \%$ (which means $<$ $0.05)$. This shows that there is a difference in students' achievement before and after the user of the learning media. From the results of the post-test average score which is higher than the average pre-test score, it can be proved that the use of the project based interactive e-module in the learning process of digital simulation can improve the students' achievement. The average score of the students' achievement was 82.65 which is higher than the score of minimum completion criteria of 75 . The effectivity level of the interactive e-module learning material in the learning process was counted by using a gain score. The scores of the pre-test and the post-test that have been obtained before were added into the formula as follows:

$<g>=\frac{\text { pasttest average score }- \text { pretest average score }}{100-\text { pretest average score }}$ 
$<g>=\frac{82.65-43.40}{100-43.40}$

$<g>=\frac{39.25}{56.60}=0.70$

The final result of the gain score is 0.70 . It was converted into again score criteria. It can be determined 0.70 score is in the high category. It can be concluded that the effectivity of the project based e-module teaching material in improving students' achievement is high. Some factors cause the difference between students' achievement score before and after using the interactive e-module. First, the module is packed in the form of electronic that directly propels the usage of multimedia features such as pictures, audios, video, and animation. This makes the module more interactive and rich in content, delivery strategies, and learning experience.

Second, the interactive e-module is combined with a project-based learning model. The implementation of the electronic teaching material supported by the right learning model will improve the effectivity of the teaching material. The project-based learning model is assessed relevant and suitable with the characteristics of the subject and the curriculum guidelines. Project-based learning model is chosen because it comes from a constructivism theory and the results of the study find out that project-based learning has some advantages, they are (a) project-based learning model improves students' ability and data collection, (b) students can develop the spirit in the team and cooperative skills, (c) students can implement their knowledge in the real world situation, (d) the achievement increases because project-based learning gives opportunity to students to know their strengths and weaknesses, and (e) students can develop presentation skills [10].

Mulyadi [11] in his research also confirms that the project-based learning model improves the performance and the achievement. Thereby, choosing a project-based learning model in e-module implementation is assessed relevant and can improve students' achievement.

\section{CONCLUSION}

Based on the results of the paired samples t-test, the significance value obtained was 0.000 (which means $<0.05$ ). This means the average score of the students' achievement before and after using the project based interactive e-module is different. The conclusion that can be drawn from the results of the t-test is that there is a significant difference between the average scores of students' achievement before and after using the project based interactive e-module. The result of the posttest average score was 82.65 which is higher than the average pretest score of 43.40. It means that digital learning using the project based interactive e-module is effective in improving students' achievement.

\section{REFERENCES}

[1] S. Budiarti, M. Nuswowati, and E. Cahyono, "Guided Inquiry Berbantuan E-Modul untuk Meningkatkan Keterampilan Berfikir Kritis," J. Innov. Sci. Educ., vol. 5, no. 2, pp. 144-151, 2016.

[2] K. R. Winatha, N. Suharsono, and K. Agustini, "Pengembangan E-modul Interaktif Berbasis Proyek Mata Pelajaran Simulasi Digital," J. Pendidik. Teknol. dan Kejuru., vol. 15, no. 2, pp. 188-199, 2018.

[3] İ. Ilter, "Educational Research and Reviews A study on the efficacy of project-based learning approach on Social Studies Education: Conceptual achievement and academic motivation," Acad. Journals, vol. 9, no. 15, pp. 487497, 2014

[4] S. E. Nayono and N. ER, "Pengembangan Model Pembelajaran Project Based Learning pada Mata Kuliah Computer Aided Design," $J$. Pendidik. Teknol. dan Kejuru., vol. 21, no. 4, pp. 340-347, 2013. 
[5] F. Movahedzadeh, R. Patwell, J. E. Rieker, and T. Gonzalez, "Project-Based Learning to Promote Effective Learning in Biotechnology Courses," Educ. Res. Int., vol. 1, no. 1, pp. 1-8, 2012.

[6] Z. Guven and T. H. Valais, "Project Based Learning: A Constructive Way toward Learner Autonomy," Int. J. Lang. Educ. Teach., vol. 1, no. 1, pp. 182-193, 2014.

[7] S. Khaliq, M. Tayyab Alam, and M. Mushtaq, "An Experimental Study to Investigate the Effectiveness of ProjectBased Learning (PBL) for Teaching Science at Elementary Level," Int. J. Acad. Res. Progress. Educ. Dev., vol. 4, no. 1, pp. 43-55, 2015.

[8] A. Marwan, "Empowering English through Project-Based Learning with ICT.," Turkish Online J. Educ. Technol. - TOJET, vol. 14, no. 4, pp. 28-37, Oct. 2015.
[9] Y. Erdogan and D. Dede, "Computer Assisted Project-Based Instruction: The Effects on Science Achievement, Computer Achievement And Portfolio Assessment," Int. J. Instr., vol. 8, no. 2, pp. 177-188, 2015.

[10] X. Wei, D. Weng, Y. Liu, and Y. Wang, "Teaching based on augmented reality for a technical creative design course," Comput. Educ., vol. 81, pp. 221-234, Feb. 2015.

[11] E. Mulyadi, "Penerapan Model Project Based Learning untuk Meningkatan Kinerja dan Prestasi Belajar Fisika Siswa SMK," J. Pendidik. Teknol. dan Kejuru., vol. 22, no. 4, pp. 385-395, Jan. 2016. 